\title{
PROPERTIES OF FIRED BODIES MADE FROM TANZANIAN TALC- CLAY MIXES FOR CERAMIC APPLICATIONS
}

\author{
EHJ Lugwisha \\ Chemistry Department, University of Dar es Salaam \\ E-mail: Esterlugwisha@yahoo.com
}

\begin{abstract}
Fired properties of talc-clay mixed bodies of different compositions were investigated for ceramic applications. Clays from Pugu and Malangali and talcs from two different sites in Kikombo deposits in Dodoma Region were used. Chemical analyses, X-ray analysis and Differential Thermal analysis for clays and talcs were used for the characterisation. Moulded mixed samples of clay and talc dried at room temperature at $110^{\circ} \mathrm{C}$ for 24 hours were fired at 1200, 1250, 1300 and $1350^{\circ} \mathrm{C}$ for 6 hours. Both clay deposits consist mainly of kaolin. Talc1 - $T_{1}$ is of higher purity than Talc $-T_{2}$. Furthermore, the percentage shrinkage of the fired crisp bodies was found to increase with temperature. Pure talcs showed the lowest amount of shrinkage while body mixes having the highest percentage of clay showed the highest amount of shrinkage. In general, the percentage of water absorption of talc-clay compositions decreased as the firing temperature was increased. Mixed bodies containing Pugu clay and those containing talc1 - $T_{1}$ have higher percentage of water absorption than those containing Malangali clay and talc $2-T_{2}$. This is due to the higher levels of impurities present in Malangali clays and high propotion of lime in talc2 $T_{2}$.
\end{abstract}

\section{INTRODUCTION}

Talc and clay are valuable materials because of their ease in forming, they are fine grained and platey, plastic, nonabrasive and easy to form. In addition, the fine grained nature of these materials is essential for the firing process. Talc and clay are raw materials which are the basis for steatite ceramics and cordierite ceramic development because they possess a distinctive set of properties that give them special character where applications are concerned (Grange 1995). In ceramic industry, the term steatite refers to fired bodies i.e. steatite ceramics, which are produced from mixes containing a major proportion of talc while for cordierite ceramics, talcs may have a more variable composition and higher impurity levels are tolerated (Grosjean 1993). On heating at $1000^{\circ} \mathrm{C}$ talc decomposes to yield a mixture of fine grained protoenstatite crystals $\left(\mathrm{MgSiO}_{3}\right)$ in a silica matrix. Increasing the firing temperature leads to crystal growth of the eustatite phase and liquid is formed at a temperature of $1547^{\circ} \mathrm{C}$.
Clays usually contain more than one mineral and the various clay minerals differ in physical and chemical properties. Increasing demands are therefore being placed on the improvement of clay mineral quality as applied to ceramics (Bloodworth et al. 1993). On heating, clay decomposes at $980^{\circ} \mathrm{C}$ to form fine grained mullite in a silica matrix. Further heating gives rise to increased growth of mullite crystals, crystallization of silica matrix to form cristobalite and the formation of eutectic liquid occurs at $1595^{\circ} \mathrm{C}$.

Kolali and Gad (1973) found that when talcclay bodies are heated, they breakdown to mullite, clinoenstatite and cristobalite. At the interface, contact will be made between all three and the large grains of clay and talc will decompose leading to cordierite formation. According to the authors, the increase of the eutectic liquid and the shortening of the firing range are achieved when the amount of clay is about 10 percent. Very large additions are disadvantageous because they raise the 
maturing temperature. So talc-clay mixes require great care in compounding and firing. With regard to the firing behaviour, this study aimed at investigating the shrinkage behaviour and water absorption of the different compositions of the clay-talc mixes.

\section{EXPERIMENT}

\section{Raw materials}

Clay and talcs used in this work were found in deposits at different sites as given below: Clays: Pugu deposit in the Coast Region Malangali deposit in Iringa Region

Talcs: Kikombo 1 and Kikombo 2 in Dodoma Region. They were coded as $T_{1}$ and $T_{2}$ respectively

\section{Chemical analyses}

The chemical composition of the samples was determined by the classical methods of chemical analysis. These methods consist of a decomposition step followed by gravimetric determination of constituent elements. Decomposition was done by using hydrofluoric acid. $50 \mathrm{mg}$ of a prepared representative sample $(<200 \mathrm{mg})$ were placed in Teflon decomposition vessel with $0.5 \mathrm{ml}$ aqua regia. $3 \mathrm{ml}$ of $\mathrm{HF}(48 \%)$ was added and the vessel tightly sealed and placed in an oven at $110^{\circ} \mathrm{C}$ for 1 hour. After cooling, the dissolution products were quantitatively transferred to a $50 \mathrm{ml}$ plastic beaker containing $2.8 \mathrm{~g}$ of $\mathrm{HBO}_{3}$. Ten $\mathrm{ml}$ distilled water were added and the mixture stirred magnetically to dissolve any insoluble fluorides. When clear, the solution was diluted to $100 \mathrm{ml}$ and stored in plastic bottle ready for major elemental analysis. (Bain and Smith 1987). Silica was determined separately. $10 \mathrm{~g}$ of each clay sample was accurately weighed into a 150 $\mathrm{ml}$ beaker. $50 \mathrm{ml}$ of conc. Hydrochloric $(\mathrm{HCl})$ acid was added and placed on a steam bath for six hours with occasional stirring and topping up with conc. $\mathrm{HCl}$ acid to replace that lost by evaporation. After sixteen hours heating the final volume was allowed to decrease to $25 \mathrm{ml}$. The solution was then diluted to about $50 \mathrm{ml}$ with distilled water and the $\mathrm{SiO}_{2}$ filtered into a sintered crucible G4. The residue was then washed with distilled water and all the filtrate and washings were collected in 100 $\mathrm{ml}$ graduated flask and reserved for the determination of metal composition while the $\mathrm{SiO}_{2}$ content in the crucible $\mathrm{G} 4$ was dried in an oven over night at $120-150^{\circ} \mathrm{C}$. The crucible was reweighed and the difference in weight was used to determine the $\mathrm{SiO}_{2}$ content in the samples (Vogel 1984).

\section{Mineralogical analyses}

The mineral constitution of the raw materials was determined by X-ray analysis and Differential Thermal Analysis. X-ray diffraction patterns were recorded in a Guinier camera fitted with quartz crystal monochromator. Philips $1010 \mathrm{X}$-ray unit with $\mathrm{CuK} \alpha$ target was used with Ni-filter. Differential thermal analysis of the samples was run on a Stanton-Redcroft Model 673-4 with an attached digital voltmeter and PC. Samples of about $150 \mathrm{mg}$ were heated at 10 ${ }^{0} \mathrm{C} / \mathrm{min}$ to about $1250{ }^{0} \mathrm{C}$ with $\mathrm{Al}_{2} \mathrm{O}_{3}$ as a reference material.

\section{Choice of composition and preparation of crisp bodies}

Series of body mixes made from Pugu clay, Malangali clay, and talc deposits $\mathrm{T}_{1}$ and $\mathrm{T}_{2}$ were prepared. Four groups of mixed compositions were prepared as given in Table 1. Mix compositions were finely ground below $0.01 \mathrm{~mm}$ diameter and mixed with $7-8 \%$ water. Small bars of $10 \mathrm{~cm}^{2}$ and $0.4 \mathrm{~cm}$ thickness were formed. This was done with the use of a hydraulic press at a pressure of $235.5 \mathrm{~kg} \mathrm{~cm}^{-2}$.

The small bars were dried at room temperature for 48 hours before drying at $110^{\circ} \mathrm{C}$ for 24 hours. This was done in order to avoid surface cracking, which might occur during firing as a result of excessive surface drying. The samples were then fired at 1200 , 1250,1300 and $1350^{\circ} \mathrm{C}$ with a residence time of 6 hours. This was done in order to monitor the fired properties and vitrification 
characteristics of the mixes. The properties are given in Fig. 3-6.

Table 1: Compositions (\% mass) of the mixes (Green bodies).

\begin{tabular}{|c|c|c|c|c|c|c|c|c|c|c|c|}
\hline GP & Sample / Mix no. & 1 & 2 & 3 & 4 & 5 & 6 & 7 & 8 & 9 & 10 \\
\hline \multirow[b]{2}{*}{1} & Pugu clay $\%$ & 90 & 80 & 70 & 60 & 50 & 40 & 30 & 20 & 10 & 0 \\
\hline & $\begin{array}{c}\text { and } \\
\text { Talc } 1-\mathrm{T}_{1} \%\end{array}$ & 10 & 20 & 30 & 40 & 50 & 60 & 70 & 80 & 90 & 100 \\
\hline \multirow[b]{2}{*}{2} & Malangali clay $\%$ & 90 & 80 & 70 & 60 & 50 & 40 & 30 & 20 & 10 & 0 \\
\hline & $\begin{array}{c}\text { and } \\
\text { Talc } 1-\mathrm{T}_{1} \%\end{array}$ & 10 & 20 & 30 & 40 & 50 & 60 & 70 & 80 & 90 & 100 \\
\hline \multirow[b]{2}{*}{3} & Pugu clay \% & 90 & 80 & 70 & 60 & 50 & 40 & 30 & 20 & 10 & 0 \\
\hline & $\begin{array}{c}\text { and } \\
\text { Talc } 2-\mathrm{T}_{2} \%\end{array}$ & 10 & 20 & 30 & 40 & 50 & 60 & 70 & 80 & 90 & 100 \\
\hline \multirow{2}{*}{4} & Malangali clay $\%$ & 90 & 80 & 70 & 60 & 50 & 40 & 30 & 20 & 10 & 0 \\
\hline & $\begin{array}{c}\text { and } \\
\text { Talc } 2-\mathrm{T}_{2} \% \\
\end{array}$ & 10 & 20 & 30 & 40 & 50 & 60 & 70 & 80 & 90 & 100 \\
\hline
\end{tabular}

\section{RESULTS AND DISCUSSION}

The chemical composition of all samples is shown in Table 2. Results which are supported by XRD patterns given in Fig. 1 and 2 show that both clay deposits consist of mainly Kaolin. $\mathrm{SiO}_{2}$ content is 46.22 and 49.81 wt $\%$ and $\mathrm{Al}_{2} \mathrm{O}_{3}$ content is 36 and $33.82 \mathrm{wt} \%$ for Pugu and Malangali clay deposits, respectively. The contents of $\mathrm{Al}_{2} \mathrm{O}_{3}$ for both clays are below the theoretical value of $39.49 \mathrm{wt} \%$ for pure kaolin. Pure kaolin has a theoretical chemical composition of 46.55 wt $\% \mathrm{SiO}_{2}, 39.49$ wt $\% \mathrm{Al}_{2} \mathrm{O}_{3}$ and 13.96 wt $\% \mathrm{H}_{2} \mathrm{O}$. However, in nature it is rarely found in pure form. The main setback in these deposits is the content of iron oxide. Malangali clays contain relatively higher amounts of iron oxide which is as high as $2.14 \%$ and other fluxes like calcium oxide $(0.85 \%)$ and magnesium oxide $(0.78 \%)$ in comparison to Pugu clays. Such a high level of iron oxide would adversely affect the translucency and colour of the finished ware. Furthermore, the chemical analysis reveals that talc $1-\mathrm{T}_{1}$ is of higher purity than talc $2-\mathrm{T}_{2}$ and is characterised by low iron oxide content and alumina while talc $2-\mathrm{T}_{2}$ show higher content of lime. Talc is a hydrated magnesium silicate with a theoretical composition of $31.7 \% \mathrm{MgO}$, $63.5 \% \mathrm{SiO}_{2}$ and $4.8 \% \mathrm{H}_{2} \mathrm{O}$. However, the composition usually varies with the locality.

Table 2: Chemical compositions of the raw materials.

\begin{tabular}{lllllllllc}
\hline \multicolumn{1}{c}{ Sample } & $\mathbf{S i O}_{2}$ & $\mathbf{A l}_{\mathbf{2}} \mathbf{O}_{\mathbf{3}}$ & $\mathbf{F e}_{\mathbf{2}} \mathbf{O}_{\mathbf{3}}$ & $\mathbf{T i O}_{\mathbf{2}}$ & $\mathbf{C a O}$ & $\mathbf{M g O}$ & $\mathbf{K}_{\mathbf{2}} \mathbf{O}$ & $\mathbf{N a}_{2} \mathbf{O}$ & $\mathbf{L O I}$ \\
\hline Pugu Kaolin & 46.22 & 36.0 & 1.40 & 0.92 & 0.29 & 0.66 & 0.39 & 0.21 & 10.81 \\
Malangali clay & 49.81 & 33.82 & 2.14 & 1.03 & 0.85 & 0.78 & 0.36 & 0.20 & 11.10 \\
Talc 1- $\mathrm{T}_{1}$ & 61.91 & 0.82 & 0.52 & - & 0.69 & 9.52 & 0.18 & 0.13 & 4.86 \\
Talc 2- $\mathrm{T}_{2}$ & 59.89 & 1.53 & 0.73 & - & 5.01 & 8.49 & 0.22 & 0.45 & 4.49 \\
\hline
\end{tabular}




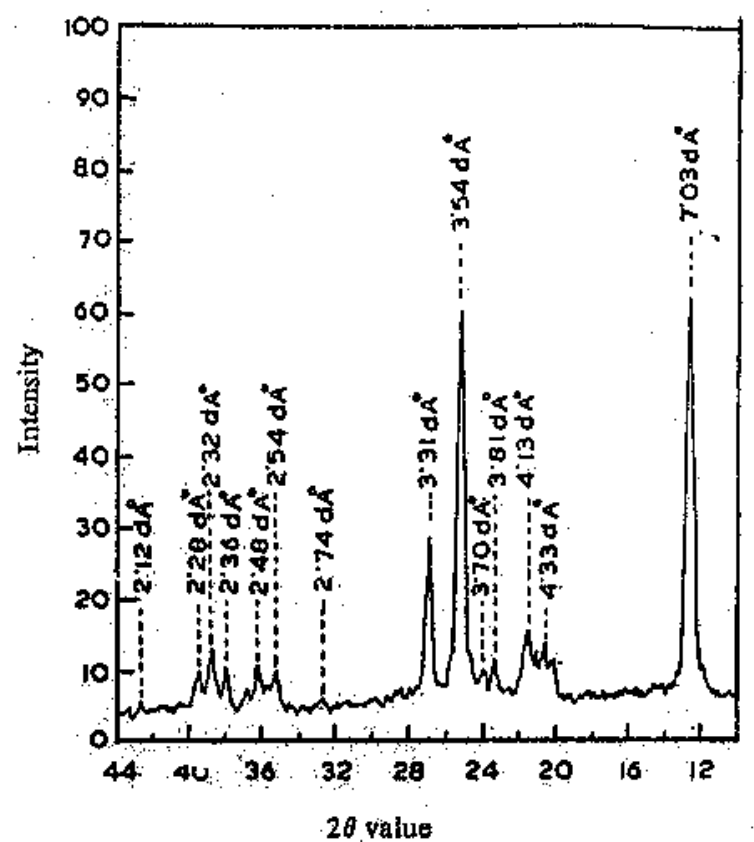

Figure 1: X-ray diffraction pattern of Pugu caly.

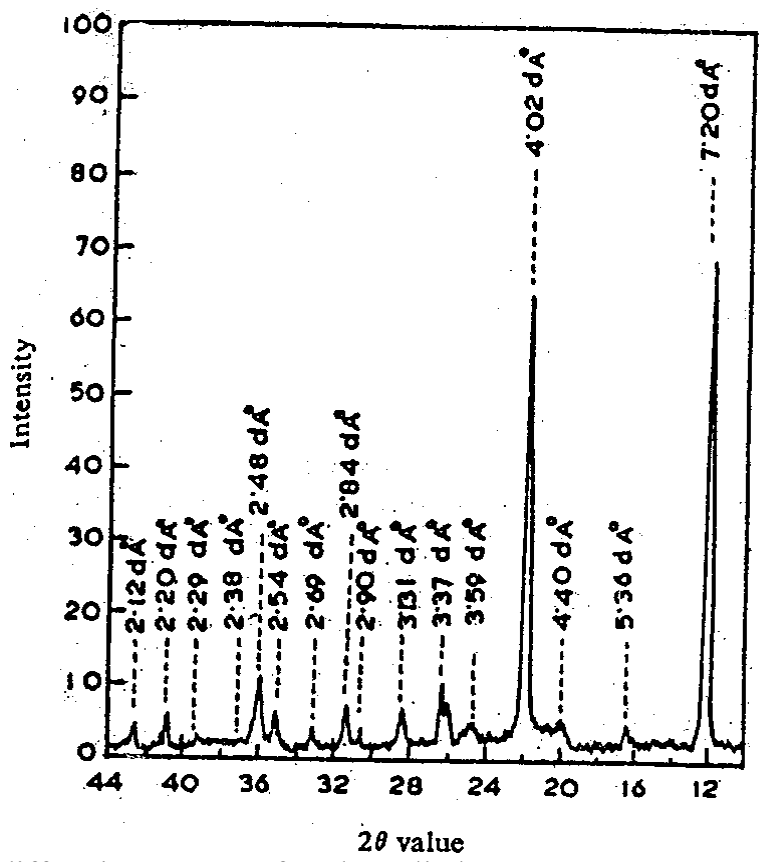

Figure 2: $\quad \mathrm{X}$-ray diffraction pattern of Malangali clay. 
The data obtained by chemical analysis correlates with the mineralogical composition of the deposits. XRD results for clays are given in Fig 1-2; both clay deposits contain mainly kaolin. The closest doublet $\mathrm{d}=4.33 \AA$ and $\mathrm{d}=4.13 \AA$ in the Pugu clay indicate the presence of a wellcrystallized kaolinite mineral which can be used in porcelain industry. These patterns are not seen in the Malangali clay. The basal reflection $d=7.03$ and $d=7.20 \AA$ for Pugu and the Malangali clays, respectively, is another indication of the presence of large proportions of kaolin in these clays. Group lines with spacing of $2.84 \AA, 2.36 \AA, 2.32 \AA$ and $2.28 \AA$ correspond also to kaolin. However, they are too faint in Malangali clay. The Malangali deposit contains also some amounts of free quartz shown by peaks at $\mathrm{d}=4.02 \AA$ and $\mathrm{d}=2.84 \AA$. Talcs consist mainly of mineral steatite as evidenced by the 002 and 020 reflections at about 4.64 and $4.52 \AA$ which are clear characteristic of talcs. These results agree with the observations made by Schuller and Kromer (1987) on the investigation they made on 50 samples from various sources worldwide.

Differential Thermal Analysis results show the thermal behaviour that is expected for kaolin (Brindley and Nakahira 1959). The endothermic dehydroxylation peak was observed between 550 and $620^{\circ} \mathrm{C}$ which indicate the formation of metakaolin. Other peaks which are exothermic peaks are observed to be centered between 950 and $965^{\circ} \mathrm{C}$. These are due to the alteration of metakaolin, which decomposes to form the cubic spinel type structure, other products include free silica and some minor amounts of mullite (Brindley and Nakahira 1959, Commer 1961).

Talc $1-T_{1}$ showed an endothermic reaction at $360^{\circ} \mathrm{C}$, which is a characteristic for the steatite mineral. While talc $2-\mathrm{T}_{2}$ showed in addition a second thermal reaction at $600^{\circ} \mathrm{C}$, which indicates the presence of some prochlorite mineral (Kolali and Gad 1973).

\section{Properties of fired bodies}

The fired properties of different mix compositions made from clay and talcs are given in Fig 3-6 for groups 1-4 mixes, respectively. Each figure consists of (a) the percentage of shrinkage and (b) the percentage of water absorption. The results show that as the temperature increases the percentage of shrinkage of the fired bodies increases too. This is reasoned to be due to the extent of sintering reactions, the amount of glass formed and the development of open or closed pores. Shrinkage is one of the physical changes, which takes place in fired bodies due to loss of open pores during the vitrification process. It is highly related to sintering. According to Lee and Rainforth (1994), sintering is the removal of pores between starting particles accompanied by shrinkage of the component combined with formation and growth of strong bonds between adjacent particles. As vitrification proceeds the proportion of glass phase increases and the apparent porosity of the fired body becomes progressively low.

It is obvious from the results that pure talcs indicate the lowest amount of shrinkage while mixes having higher percent of clay show the highest amount of shrinkage. It must be remembered that firing shrinkage varies with composition and also tends to increase as the fluxing components increase with the production of relatively more glassy material and less amount of high temperature crystallined phases during firing. So in this case the highest amount of shrinkage observed in clays is attributed to the higher amounts of fluxes present in clays.

Earlier work by Kobayashi et al. (1991) shows that bodies with high silica content normally have low shrinkage during firing. Therefore the low shrinkage of pure talc might also be due to this fact. Talcs consist of higher contents of silica, normal talc has $\mathrm{SiO}_{2}$ content of about $63.7 \%$ but values can vary depending on the locality where talc 


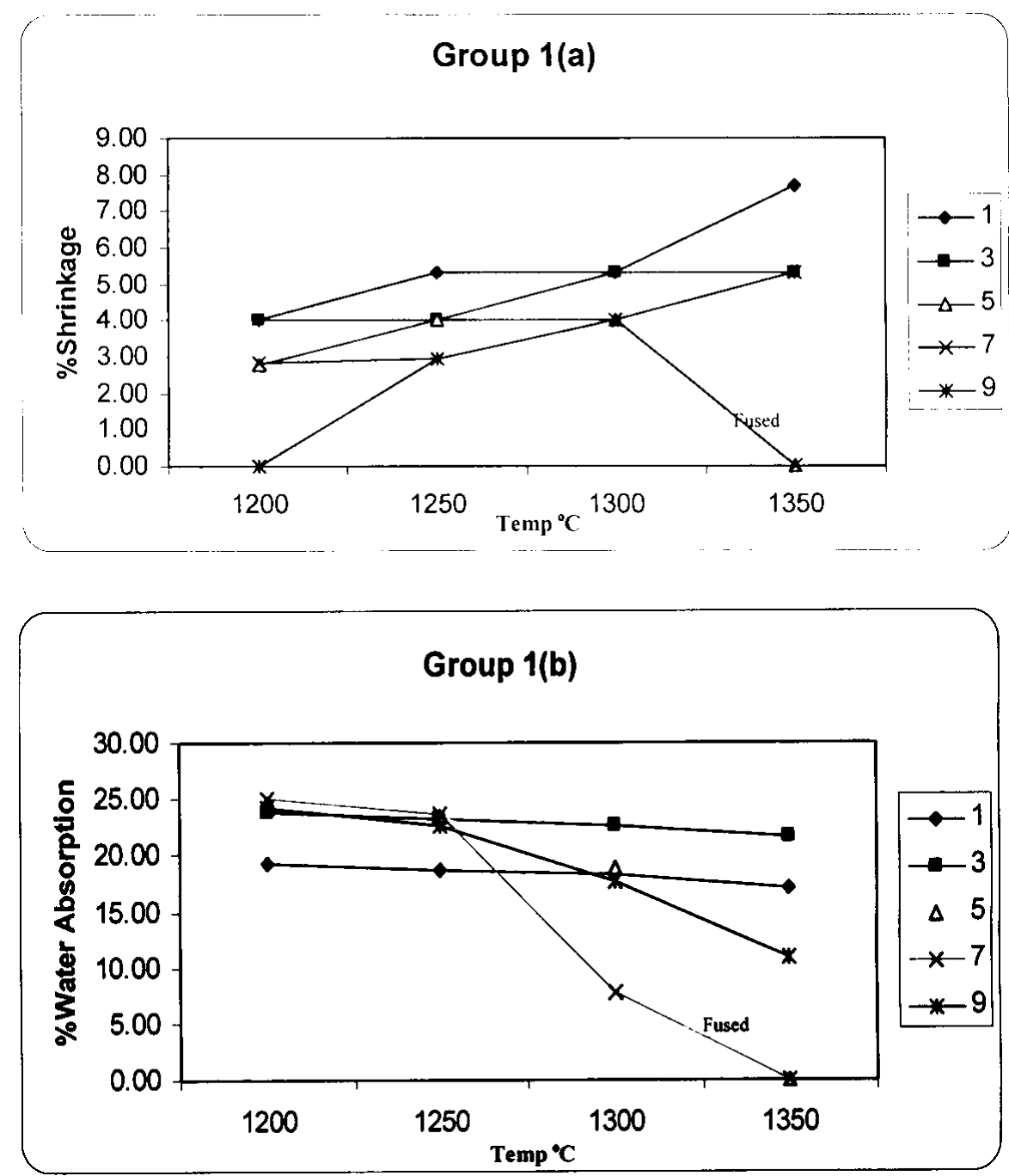

Figure 3: $\quad$ Fired properties of Pugu clay and $\mathrm{T}_{1}$ mixes:
(a) \% Shrinkage
(b) $\%$ water absorption 

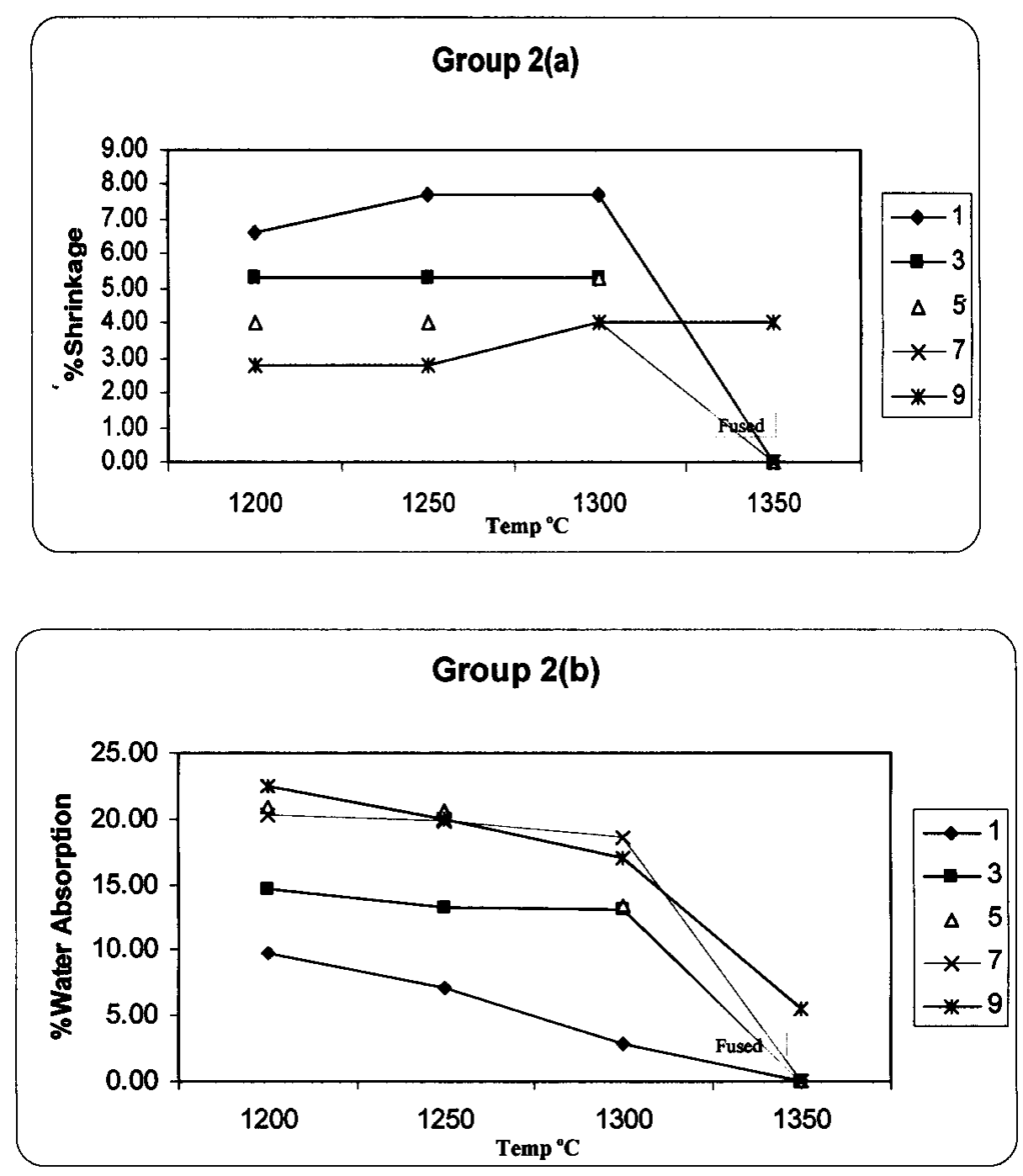

Figure 4: Fired properties of Malangali clay and $\mathrm{T}_{1}$ mixes:
(a) \% Shrinkage
(b) $\%$ water absorption 

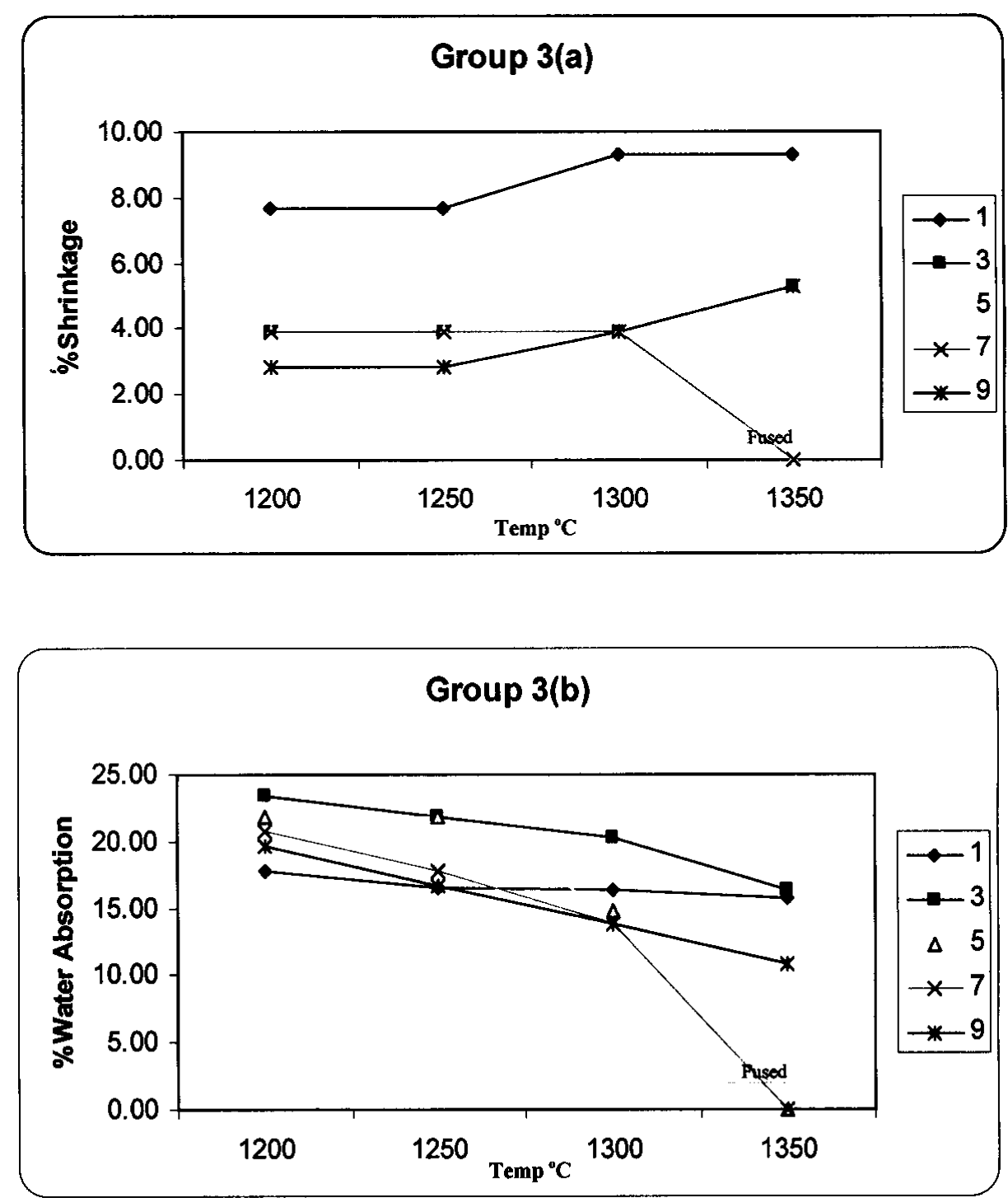

Figure 5: $\quad$ Fired properties of Pugu clay and $\mathrm{T}_{2}$ mixes:
(a) \% shrinkage
(b) \% water absorption 

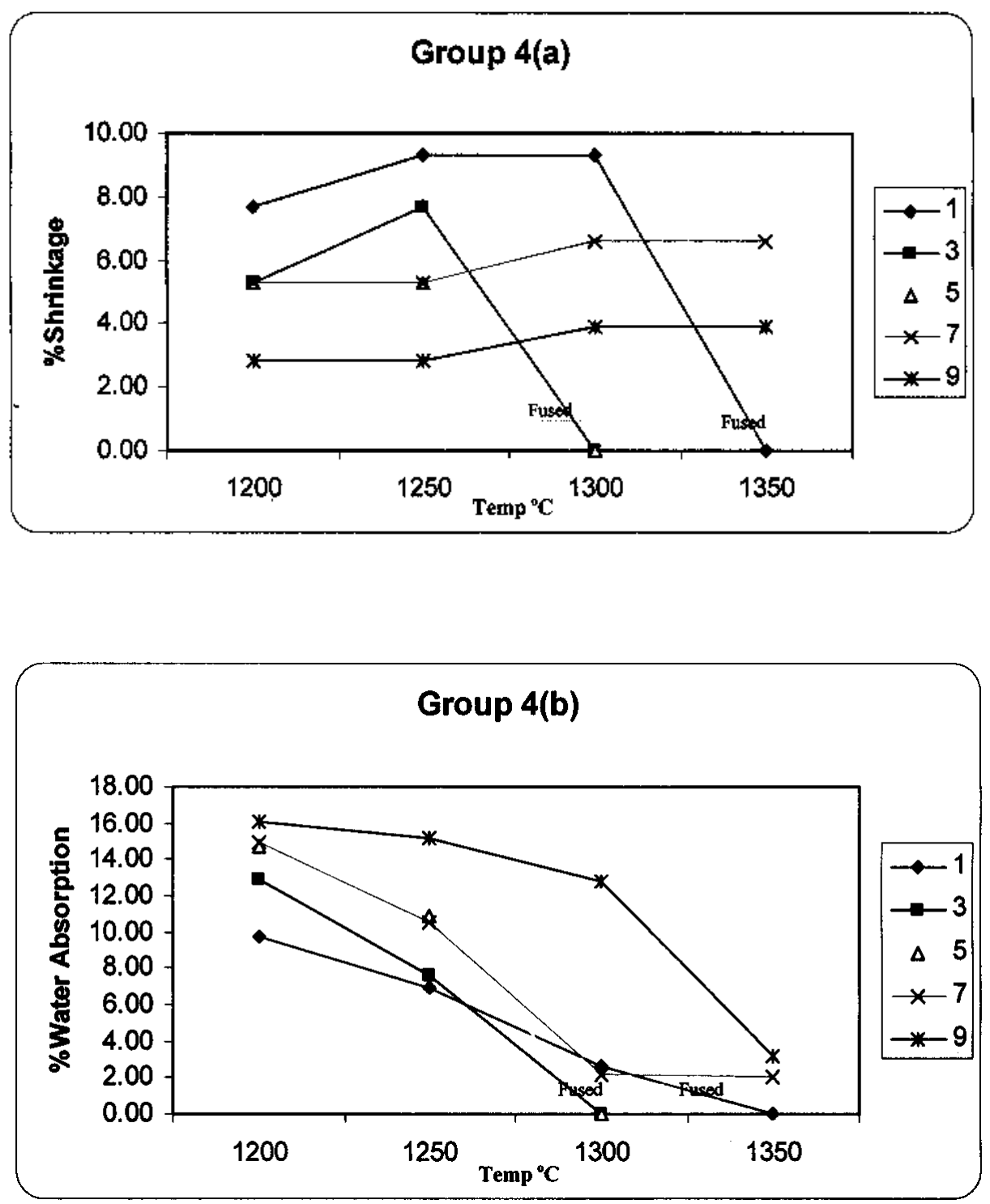

Figure 6: $\quad$ Fired properties of Malangali clay and $\mathrm{T}_{2}$ mixes:
(a) \% shrinkage
(b) $\%$ water absorption

Another observation regarding percentage of shrinkage is that, crisp bodies containing the Malangali clay, show higher amounts of shrinkage in general compared to Pugu clay. No satisfactory explanation of these observations has been offered but probably it is due to presence of fluxes like calcium oxide $(0.85 \%)$, magnesium oxide $(0.78 \%)$ and iron oxide $(2.14 \%)$ which are relatively higher in the Malangali clay than in the Pugu clay.

In contrast to the shrinkage, results obtained have shown that the percentage of water absorption of the fired bodies decreases as the temperature increases. This is due to the 
vitrification rate, which increases with the increase of temperature. As indicated previously, among the physical changes which take place during vitrification process in ceramic bodies is loss of open pores (shrinkage) and development of closed pores. As the temperature is raised the rate at which these physical changes take place is increased and leads to less water absorption.

Comparison of the fired mixed bodies of clay-talc shows that mixed bodies containing the Pugu clay has higher water absorption than those containing the Malangali clay. The explanation for this observation is viewed in terms of the higher levels of impurities present in Malangali clay and, accordingly, their vitrification rate is high. Furthermore, mixed bodies containing talc $1-\mathrm{T}_{1}$ showed higher percentage of water absorption than those containing talc $2-\mathrm{T}_{2}$. This is attributed to the fact that talc $1-T_{1}$ is purer compared to talc $2-\mathrm{T}_{2}$ which contains high percent of lime.

As shown earlier, fusion for certain mix compositions takes place at $1350^{\circ} \mathrm{C}$. So far as the clay deposits are concerned mixed compositions which are fused are the ones which consist of mixes between $90 \%$ and $30 \%$ clay and between $60 \%$ and $20 \%$ clay for the Malangali and Pugu clays, respectively. No explanation has yet been given for this observation - as the work is still in progress.

These findings have also showed that mixtures containing between $90 \%$ and $60 \%$ clay showed wide firing range. Such mixed bodies can be used for the manufacture of ceramic bodies because they form basis of the cordierite bodies. On the other hand, mixtures of bodies consisting of $90 \%$ and $80 \%$ talc have a wide range of vitrification and thus are suitable for the manufacture of steatite ceramic bodies.

\section{CONCLUSION}

The present work was carried out to investigate the fired properties of the talcclay mixed bodies for the ceramic application. Two properties, namely shrinkage and water absorption were studied. Results showed that usage of these mixes in ceramics could be achieved through proper mix compositions and appropriate firing temperatures. This study also showed that different mix compositions are tailored towards specific ceramic applications. For instance mixed bodies consisting of $90 \%$ and $60 \%$ clay, and $10 \%$ and $40 \%$ talc, respectively, could be used for the production of cordierite ceramic bodies. The applications evaluated in this study are not the only ones for the ceramic industry, there are many others. So besides the two fired properties studied, a further study should therefore be carried out on other properties like thermal expansion and thermal shock resistance just to mention a few, to enable the evaluation of other applications for various mix compositions.

\section{ACKNOWLEDGEMENT}

I am grateful to NORAD and GDPC (University of Dar es Salaam) for the financial support. Many thanks to Dr. Heal R.G. of the University of Salford for availing to me laboratory space and experimental facilities. I also want to thank Mr. Matemu of SEAMIC for helpful discussion and for providing me with reading materials relevant to this work.

\section{REFERENCES}

Bain DC and Smith BFL 1987 Chemical Analysis In: Wilson MJ (ed) $A$ Handbook of Determinative Methods in Clay Mineralogy. Chapman and Hall, New York.

Bloodworth AJ, Highley DE and Mitchell CJ 1993 Industrial Minerals Laboratory Manual: Kaolin. BGS Technical Report WG $/ 931 / 1$

Brindley GW and Nakahira M 1959 The Kaolinite - Mullite Reaction Series 
Parts I, II, III. J. Amer. Ceram. Soc. 42 (7): 311-324.

Commer JJ 1961 New Electron - Optical Data on the Kaolinite - Mullite Transformation. J. Amer. Ceram. Soc. 44 (11): $561-63$.

Grange JP 1995 Talc: Innovate to survive competition. Miner. Ind. Int. 17 - 19.

Grosjean P 1993 Cordierite Ceramics. Interceram. 42 (1): 11-15.

Kobayashi Y, Ohira O, Ohashi Y and Kaloli E 1991 J. Ceram. Soc. Jpn 99 (6): 495 502.

Kolali AA and Gad G 1973 Talc-Clay Ceramic bodies Ind. Cer. 17 (2): 101106.
Lee WE and Rainforth WM 1994 Ceramic Microstructures Property Control by Processing. Chapman and Hall, London.

Schuller KH and Kromer H 1987 Properties of talc and steatites with emphasis on ceramic applications In: Schultz LG, Olphen HV Mumpton FA (eds). The Clay Minerals Society: 396-399 Proceedings of International Clay Conference Denver Bloomington Indiana.

Vogel A 1978 Textbook of Quantitative Inorganic Analysis. $4^{\text {th }}$ edn, Longman Inc, New York. 